\title{
Development of Module MYOB Accounting Undergraduate Study Program for the Students of Accounting Education
}

\section{Rochmawati, Suci Rohayati, Agung listiadi, and Irin Widayati}

Faculty of economic, Universitas Negeri Surabaya, Surabaya-Indonesia

\section{Abstract}

The purpose of this research is to develop a module MYOB Accounting for the students of Accounting study. At the time of this study, the module used for teaching MYOB Accounting in Labs were still the module-based vocational high school, and researchers want to update such content with the present. The module MYOB Accounting is expected to facilitate students to understand MYOB Accounting courses. The results of a study using MYOB module is more increased than before.

Keywords: development, module MYOB Accounting, learning outcomes
Corresponding Author:

Rochmawati

rochmawati@unesa.ac.id

Received: 29 January 2019

Accepted: 27 February 2019

Published: 24 March 2019

Publishing services provided by Knowledge E

(c) Rochmawati et al. This article is distributed under the terms of the Creative Commons

Attribution License, which permits unrestricted use and redistribution provided that the original author and source are credited.

Selection and Peer-review under the responsibility of the 3rd ICEEBA Conference Committee.

\section{G OPEN ACCESS}

\section{Introduction}

An educator in College in this case professors considered more aware of and understand the State of the class so that way the attainment of competencies is the authority of educators for activity through the learning device, learning strategies, methods learning as well as his. Skills and competence that owned the educator is helpful in reaching a successful learning. For that an educator is required must be able to determine and choose a suitable learning strategy and varied. According to Robertson (2008) every educator has the ability, that ability is affected from the individual, or the bringing of born and environmental factors. Therefore the ability of educators required in his job as a lecturer to conduct learners out teaching and learning actively.

Learning materials is an important part in the implementation of the education at the school. Through the learning materials teacher/lecturer will be easier in implementing learning and more student helped as well as facilitate students in learning. Learning materials can be made in different shapes according to the needs and characteristics of the learning material will be presented (Mone, 2008:4). The materials can be printed materials such as handouts, books, modules, categorize, leaflets, wallchart, photos or images (Prastowo, 2014:40). 
The development of science and technology, bringing changes to the learning materials (learning materials). Before the rise of computer technology learning materials that are the subject matter used in the educational world is all that is printed material, such as books, modules, paper and others that use printed material (Darmawan: 2012.54). Any change in the field of information technology, particularly the technology brings a new paradigm in learning the material. IT has adult products provide an alternative form of learning materials that can be used and accessed by students who are not in the form of paper, but shaped CD, DVD, Flash and others. The core of the material is in the form of the program (software) that can be used to simply to get data, read, download and even interact among programs with students and teachers by making use of the computer as the primary device. The computer is not only meant as a science to be learned students but the computer as a tool that helps to learn a wide range of subject matter. In more complex systems, IT integrates cloud-based computer program so that it gives the e-book, e-learning, e-journal and others (Darmawan: 2012.54).

Learning materials developed by researchers at the moment is the module. According to Nasution (2006:173) module can be formulated as a complete unit in its own right and consists of a series of organized learning activities to help students achieve a number of objectives that are specifically formulated and clear. The teaching module is the teaching that partially or completely based on the module.

MYOB Accounting study which was carried out in the laboratory of the Faculty of Economics of Unesa during this still uses the module based Vocational high school (SMK). Researchers want to develop a module that already exists on the CMS with the corresponding adjustment with MYOB Accounting data. The purpose of this module is to develop the student easier understand MYOB Accounting.

Some previous research that support in this research is the Moh Slamet Fauzi (2016) module Development computer accounting transaction evidence approach is said to be very viable. Furthermore, water Yana (2017) the development of learning materials teaching MYOB accounting with Accounting at the Undergraduate Economics Education research results say it deserves with the percentage of $85 \%$. As well as research carried out by Su-Hie Ting (2012) entitled 'Learning References in Printed and Online Mediums For Academic Purposes'. This study examines the full preferences for print reference to learn in the language of the United Kingdom for the purpose of academic researchers are therefore trying to develop Module as the expected learning materials so that students are able to learn with minimal assistance from educators and have no trouble against MYOB Accounting subjects. 
Based on explanation above, researchers want to do research on the development under the title 'development of Module MYOB Accounting Undergraduate Study Program for students of Accounting Education'.

\section{Research Methods}

Development model can be either procedural model, the conceptual model and teoritik model. Procedural model is a model that is descriptive, that outline the steps to follow to produce a product. The implementation of this model of development is a product module MYOB accounting education for the students. The development model used IE development model according to Tiagarajan (in Trianto), that is, model $4 \mathrm{~d}$ development (four D method) that consists of a definition phase (Define), stage the restyling (Design), stage of development (Develop), and stage deployment (Disseminate).

\section{Results of the Research}

\subsection{Module development process}

This discussion presents the overall results of the development of a detailed and clear. The discussion presented in the form of the eligibility process and materials module MYOB for college students. The overall process of developing a module MYOB for student education on accounting material trading company at the Faculty of Economics of the Unesa get learning Accounting has been in accordance with the model development of 4-D (four D Models)-stage definition (define), stage design (design), stage of development (develop) and the spread (disseminate).

\subsubsection{Stage definition (Define)}

At this stage the definition of done front end analysis, analysis students, analysis tasks, concepts, analysis and formulation of learning objectives. The first phase, that is, researchers do the front end where the analysis in this analysis searched for basic problems that occur on the computer learning accounting 1 in student faculty of Economics economy education Unesa namely that learning computer MYOB accounting modules still using CMS. Therefore researchers develop module MYOB accounting education for the students. The second stage, namely the analysis of the student/student student/analysis, aims to find out students ' cognitive ability, where the cognitive ability 
of the students there are on the level of implementation and analysis. The third stage, namely the analysis of the tasks, so that students/student is able to understand the whole process of preparing the financial statements, then the student/student is given the task of drawing up the financial statements the accounting cycle trading companies using evidence the real, and to familiarize students with the accounting work through IT then the process of the preparation of modules is done using MYOB accounting applications help. The fourth stage, namely the analysis of the concept, the analysis of this concept aims to identify the concept of material that will be used by students/students in learning activities. As for the concept developed is the accounting cycle trading companies. On the fifth stage, namely the formulation of learning objectives, this stage is done for the Foundation of learning in knowing the level of the achievements of student/students in teaching and learning activities. the analysis of the five, then it can be concluded that the problem could be addressed by developing learning materials module MYOB accounting education for the students of economic faculties of Unesa.

\subsubsection{Stage design (Design)}

At this stage is done making frame lattice problem which includes election forms and types of test tools evaluation of learning. The selection of shapes and types of tests done adjusted to the material to be used. The selection of material ranging from the creation of the company name, the creation and deletion of accounts, financial reporting and journaling trading company. Module MYOB accounting education for the students of this form of learning materials can be seen and held by students/students directly as it has existed physically.

\subsubsection{Stages of development (Develop)}

This stage begins with the examination of expert evaluation and expert material later revisions that result in draft 2 and validated by experts. After becoming draft 2 , next module MYOB already compiled in a test question to know the quality of modules in understanding the process of preparation of the financial statements. After doing a test problem then perform revisions that would eventually produce a draft 3. After becoming draft 3 , conducted trials are limited to 20 students who get learning in accounting. From the limited testing conducted a revision to the refinement of materials module MYOB. The last development stage is the revision of the draft 3 based on input from a limited trial so that it becomes the final draft. The results of validation against materials module 
MYOB accounting cycle material trading company according to the validator material stating that the material module MYOB deserves to be used in the learning process accounting. Most of the students gave a positive response or responses to any aspects that are asked in the question form student response sheet/students against module developed by researchers. From the results of trials are limited, students stated that the materials used in the module's worth to help you understand the process of preparation of the financial statements the accounting cycle trading companies are purely procedural

\subsubsection{Deployment phase (Disseminate)}

At this stage it is only done in the student's education of accounting economic faculty of Unesa.

\subsection{Feasibility of module}

At this stage the feasibility of module MYOB judged from validator expert material. Assessment of eligibility according to the criteria of getting material very well, this is because the modules developed by the researchers are procedural from the beginning of the process until the company name income by making the financial report that includes income statements, capital changes reports and the report of the financial position of the company. In addition the modules developed by researchers are contextually with the acquisition value been $81 \%$ and got a very decent criteria according to the Riduwan 2016.

\subsection{Learner response against module MYOB}

At this stage is the stage of the collection of response learners/students of accounting education, of the 20 respondents results can be presented as follows: (1) aspects of the content of the material showed $85 \%$ very familiar criteria; (2) the representation aspect shows $75 \%$ criteria be familiar; (3) the linguistic aspect shows $76 \%$ with familiar criteria; (4) graph aspect shows $81 \%$ very familiar.

\subsection{Learning outcome}

The results of student learning by using learning materials module MYOB accounting education for students increasing this can be seen in the acquisition of values by using 
a module then worth 78 up to 90 . This indicates that the presence of the module then the students find it easy to exercise the accounting cycle trading companies with the help of MYOB accounting software and if the students have forgotten or missed then a student can open a module so that the existence of the module then the role of lecturer only as a facilitator in this regard in accordance with his theory Nasution (2006:173) module can be formulated as a complete unit in its own right and consists of a series of learning activities that are structured to help students achieve a number of objectives that are specifically formulated and clear.

\section{Summary and Suggestions}

\subsection{Summary}

Based on the results of the above discussion, so researchers can conclude as follows: (1) the process of developing a module MYOB accounting material trading company in accordance with the model development of $4 \mathrm{~d}$ Thiagarajan with define, design, develop and disseminate; (2) the module MYOB accounting gets the eligibility criteria is very worthy of a material; (3) the response of the students against the module MYOB; (4) the learning outcomes of students increased.

\subsection{Advice}

After the research is done, then the researchers gave advice to researchers next as follows: (1) Required cooperation with expert graphic design; (2) Required cooperation with trade/retail companies that have a sufficiency of evidence of transactions and (3) Required cooperation with the Association of the accounting profession.

\section{References}

[1] Badan Standar Nasional Pendidikan. (2014). Naskah Akademik Instrumen Penelitian Buku Teks Kelayakan Kegrafikan. Jakarta: BSNP

[2] Darmawan, D. (2012). Inovasi Pendidikan Pendekatan Praktik Teknologi Multimedia dan Pembelajaran Online. Bandung: PT Remaja Rosdakarya Offset.

[3] Daryanto, D. (2013). Media Pembelajaran Peranannya sangat penting Dalam Mencapai Tujuan Pembelajaran. Yogjakarta: Gava Media. 
[4] Depdiknas. (2008). Panduan Pengembangan Bahan Ajar. Jakarta: Direktorat Pembinaan SMA, Dirjen Mandikdasmen, Depdiknas.

[5] Hamalik, O. (2014). Kurikulum dan Pembelajaran. Bandung: Bumi Aksara.

[6] Nasution, S. (2006). Berbagai Pendekatan Dalam Proses Belajar \& Mengajar. Bandung: Bumi Aksara.

[7] Prastowo, A. (2014). Panduan Kreatif Membuat Bahan Ajar Inovatif. Yogyakarta: DIVA Press.

[8] Prastowo, A. (2015). Panduan Kreatif Membuat Bahan Ajar Inovatif Menciptakan Metode Pembelajaran yang Menarik dan Menyenangkan. Yogyakarta: Diva Press.

[9] Pribadi, B. (2010). Model Desain Sistem Pembelajaran. Jakarta: Dian Rakyat.

[10] Riduwan. (2015). Skala Pengukuran Variabel-variabel Penelitian. Bandung: CV Alfabeta.

[11] Slameto. (2009). Belajar dan Faktor-Faktor yang Mempengaruhinya. Jakarta: Rineka Cipta.

[12] Sugiyono. (2013). Metode Penelitian Pendidikan Pendekatan Kuantitatif, Kualitatif dan R\&D. Bandung: Alfabeta.

[13] Ting, S.-H. and Puteh, F. (2012). Learning References in Printed and Online Mediums For Academic Purposes, vol. 66, pp. 290-301. Retrieved from: https://www. sciencedirect.com/science/article/pii/S1877042812052561 (accessed on December 10, 2017).

[14] Usman, U. (2006). Menjadi Pendidik Profesional. Bandung: PT. Remaja Rosdakarya. 